\title{
Cutaneous Melanoma pM1 TNM Finding v6
}

National Cancer Institute

\section{Source}

National Cancer Institute. Cutaneous Melanoma pM1 TNM Finding v6. NCI Thesaurus. Code C48866.

Cutaneous melanoma with distant metastasis. (from AJCC 6th Ed.) 